\title{
Effect of diets containing tuna head hydrolysates on the survival and growth of shrimp Penaeus vannamei
}

\author{
Huong Thi My Nguyen ${ }^{a, b, *}$, Raúl Pérez-Gálvez ${ }^{c}$, Jean Pascal Bergé ${ }^{b}$
}

\author{
a Nha Trang University, 2 Nguyen Dinh Chieu, Nha Trang, Vietnam \\ ${ }^{b}$ IFREMER, rue de l'île d'Yeu, BP 21105, 44311 Nantes, France \\ ${ }^{c}$ Department of Chemical Engineering, University of Granada, 18071 Granada, Spain \\ *: Corresponding author : Huong Thi My Nguyen, Tel.: + 84914074499 ; fax: + 84583831147 ; \\ email address : huongdhts@yahoo.com
}

\begin{abstract}
:
A feeding trial was conducted to evaluate the effect of the supplementation of hydrolysates from tuna head on the survival and growth of Penaeus vannamei. To this end, a feeding trial was performed on eleven groups of shrimps of average weight $4.34 \mathrm{~g}$. Every group was distributed into three tanks (30 shrimps per tank of $150 \mathrm{~L}$ ) and was fed with one of the following eleven diets, all of them containing $40 \%$ crude protein: one diet containing tuna head meal as the principal protein source, which was used as control diet; nine diets formulated by replacing $50 \%$ tuna head meal by fish protein hydrolysates (FPH), and finally one commercial diet chosen as a reference. FPH were obtained by hydrolysis of tuna head during 2, 3 or $6 \mathrm{~h}$ and ulterior centrifugation in order to recover an aqueous fraction containing soluble protein and a solid sludge. 9 different diets were formulated according to the origin of the FPH: three diets DS2, DS3 and DS6 containing the soluble protein powders (dry extract from the aqueous fraction) recovered after 2, 3 and $6 \mathrm{~h}$ of hydrolysis, respectively; 3 diets supplemented with insoluble protein powers DI2, DI3, DI6 (obtained after drying the solid sludge) and 3 diets containing a mixture of both soluble and insoluble protein powers DM2, DM3, DM6. After 6 weeks of experiment, the survival, gain weight, feed conversion ratio and protein efficiency ratio were compared between the different groups. The present study showed that the diets supplemented with soluble protein powders (DS2, DS3 and DS6), as well as one containing insoluble protein powder (DI2) from the hydrolysis of tuna head improved significantly the four zootechnical parameters studied. On the contrary, the survival rates and growth performances for the groups fed with the diets containing a mixture of protein powders were not significantly different or even lower compared to the control and the commercial diets. It was concluded that fraction separation after hydrolysis had a positive effect on the zootechnical performance of the formulated diets.
\end{abstract}

\section{Highlights}

Feeding trial was conducted to evaluate the effect of hydrolysates on the growth of shrimp. Diets supplied with soluble protein powders improved the growth of shrimp. Diets containing insoluble protein powders also improved the growth of shrimp. Incorporation of mixtures of protein powder did not improve the growth of shrimp.

Keywords: Tuna ; Head ; Fish protein hydrolysates ; Growth of shrimp 


\section{Introduction}

In commercially manufactured shrimp feed, marine protein sources as fish and squid meals are one of the primary protein sources due to their content in essential amino acids, fatty acids, vitamins and minerals. Indeed, shrimp culture depends on fish meal supplementation to fulfill the protein requirements. In 2006, a global survey over 50 countries has estimated that the aquaculture sector consumed 3724 thousand tons of fish meal, mostly devoted to marine shrimp and salmon culture aquafeeds (Tacon and Metian, 2008). This study has also predicted that the use of fish meal in aquaculture will decrease in the long term (44.5\% decrease expected from 2005 to 2020) due to the reducing availability of fish meal from capture fisheries and the increasing use of cheaper protein sources from plant and animal origin. In this context, aquaculture should reduce its current dependence on fish meal production and promote a better utilization of fishing sources (i.e. by employing fish by-products as protein or lipid sources).

Based on their good functional properties and nutritive value, fish protein hydrolysates are potential ingredients able to replace or complement fish-meal-based diets in aquaculture diets. Indeed, they have been so far used in aquaculture feeds as protein supplement, attractants or palatability enhancers (Hardy, 1991; Aguila et al., 2007). Enzymatic hydrolysis of fish materials is usually carried out under mild conditions, giving rise to final products of high functionality, good organoleptic properties and excellent nutritional value without formation of toxic compounds (Kristinsson and Rasco, 2000).

Besides their functional properties, some authors have reported biological activities on fish protein hydrolysates such as antioxidative, antihypertensive or antimicrobial (Klompong et al., 2007; Thiansilakul et al., 2007). The use of fish protein hydrolysate in diets has proved to improve growth and feed utilization (in terms of protein efficiency and nutrient retention) of salmonids (Berge and Storebakken, 1996; Refstie et al., 2004) and carp larvae (Carvalho et al., 1997). Some studies on fish larvae growth confirm that feeds with fish protein hydrolysate supplement improve both growth and digestive system development (Zambonino-Infante et al., 1997; Day et al., 1997; Cahu et al., 1999). In the field of crustacean culture, Anggawati et al. (1990) incorporated fish hydrolysates into the diet of giant tiger prawn (Penaeus monodon). They found that replacing $3 \%$ fish meal by fish hydrolysate was enough to enhance shrimp growth.

The objective of this study was to investigate the possibility of incorporating protein hydrolysates from Yellowfin tuna head in feed for white shrimp (Penaeus vannamei) and to compare the zootechnical performances such as survival rate, weight gain, feed conversion ratio and protein efficiency ratio in the groups of shrimp fed the diets containing different hydrolysates.

\section{Materials and methods}

\subsection{Dietary protein ingredients}

Yellowfin tuna (Thunnus albacares) were caught in the Pacific Ocean in April 2008 and were filleted at the seafood processing company Hai Vuong in Nha Trang, Vietnam. Tuna heads were collected, frozen and transported to Nha Trang University. Tuna heads were employed as raw material for both fish meal and fish hydrolysates.

Minced tuna head was homogenized with an equal volume of distilled water and was enzymatically hydrolysed with Protamex, provided by Novozymes AS (Denmark). Enzyme was added at $0.5 \%$ of the 
weight of tuna head. Three hydrolysis were carried out at $45^{\circ} \mathrm{C}$ and natural substrate $\mathrm{pH}$ (initial $\mathrm{pH}=$ 6.5) during $2 \mathrm{~h}, 3 \mathrm{~h}$ and $6 \mathrm{~h}$. To stop the proteolysis reaction, the mixture was heated at $95^{\circ} \mathrm{C}$ for 15 minutes in order to inactivate enzyme. It was then filtered to separate the bones and the resulting filtrate was then centrifuged at $10,000 \times \mathrm{g}$ and $4^{\circ} \mathrm{C}$ during 30 minutes. After centrifugation, three fractions were recovered: an oily phase, an aqueous fraction and a solid sludge.

Two kinds of protein products were thus produced. The first ones by freeze drying the soluble phases leading to the soluble protein powders: S2, S3 and S6 for 2, 3 and 6 hours of proteolysis respectively. The second ones by drying at $40^{\circ} \mathrm{C}$ the insoluble sludges, leading to 12,13 and 16 for 2,3 and 6 hours. In addition, a third category of powder was also produced. In this case no centrifugation has occurred after thermal inactivation of the enzyme. Thus, oily phase, aqueous phase and sludge were not separated. Bones were removed by filtration and the filtrates were freeze-dried to obtain mixture protein powders (M2, M3 and M6).

Those nine different powders were incorporated into the diet of shrimp as protein sources and were substituted to part of the fish meal from yellowfin tuna head, which constituted the major ingredient of the whole shrimp diet, together with soybean meal, rice bran and wheat. This fish meal was directly obtained from the Yellowfin tuna head while the three vegetal ingredients were supplied by the Long Hiep company, which produces feed for shrimp culture in Nha Trang, Vietnam. Proximate composition of the dietary protein ingredients incorporated into each diet is given in Table 1.

\subsection{Experimental diets}

Ten diets, containing 40\% crude protein (dry weight basis) were formulated. The control diet (CD) contained tuna head meal as major protein source. The nine remaining diets were formulated by replacing $50 \%$ of the tuna head meal by the tuna head powders, as presented in Table 2 . The diets DS2, DS3 and DS6 contained the soluble protein powders S2, S3 and S6, respectively, while those noted as DI2, DI3 and DI6 contained the insoluble protein powders 12, I3 and 16. Three additional diets, noted as DM2, DM3 and DM6, were formulated by substituting $50 \%$ of the tuna head meal by the mixture of the protein powders (soluble + insoluble) M2, M3 and M6. The control and the nine formulated diets where completed with $15 \%$ soybean meal, $10 \%$ rice bran and $3 \%$ mineral and vitamin mixture. The ingredient composition of the ten diets is presented in Table 2. All the diets produced had a pellet size of $2 \mathrm{~mm}$ and were stored at $4^{\circ} \mathrm{C}$ until utilization. Every diet was characterized in terms of proximate composition and amino acid profile, as presented in Tables 3 and 4, respectively.

\subsection{Shimp, feeding trial}

The shrimps chosen for the feeding trials belonged to the species Penaeus vannamei, with an average weight of $4.34 \pm 0.08 \mathrm{~g}$. They were supplied by the Center for Aquaculture Research of the Nha Trang University (Vietnam).

The feeding trial was carried out at the Nha Trang University during 6 weeks to determine the effect of those experimental diets on the survival and growth of shrimp and compared to one commercial diet (RD) supplied by the Uni-President company (Vietnam) which was used as a reference.

This feeding trial was carried out using 33 tanks of capacity $150 \mathrm{~L}(50 \times 60 \times 50 \mathrm{~cm})$. These tanks were installed in a water recirculation system which included a settling tank, a biological filter and a pump. At the beginning of experiment, 11 groups of shrimps were randomly distributed from the holding vessels to the feeding tanks (30 shrimps per tank). Each diet was provided to 3 tanks and the daily feed ration was fixed to $5 \%$ of the initial shrimp weight. Shrimps were fed by hand twice daily at $8 \mathrm{~h}$ and $17 \mathrm{~h}$. At each feeding, the diet corresponding to each tank was distributed over one feeding tray of $30 \mathrm{~cm}$ diameter. The feeding trays were removed $3 \mathrm{~h}$ after each feeding and the uneaten feed was 
collected separately from each tank and frozen at $-20^{\circ} \mathrm{C}$. At the end of experiment, these uneaten feed of each tank were dried at $105^{\circ} \mathrm{C}$ until constant weight and then weighted.

The weight of the shrimps was measured every 3 weeks and the daily feed ration per tank (5\% of the total weight of shrimps in a tank) for the 3 next weeks was readjusted on the basis of this control.

All tanks were cleaned daily by siphoning off accumulated waste materials. During the experimental period, the water temperature ranged from 27 to $29^{\circ} \mathrm{C}$, dissolved oxygen varied from 5 to $6.5 \mathrm{mg} / \mathrm{L}$, salinity ranged from 23 to $26 \%$, pH ranged from 7 to 8 .

\subsection{Survival rate and growth parameters}

The survival rate was defined as the ratio between the number of living shrimps at the end and the beginning of the experiment. The absolute weight gain (AWG) was calculated by the difference between the mean weight at the end and the beginning of the experiment. This variable was also related to the initial mean weight, obtaining the relative weight gain (RWG).

Besides the weight gain, other growth-related parameters were determined, in order to evaluate both the feed utilization by the shrimps (feed intake FI) and the effect of feed intake on the weight gain (feed conversion ratio FCR and protein efficiency ratio PER). Since the diets were immersed in water during the assays, water stability tests were performed to account for the loss of dry matter (LDM) and loss of crude protein (LCP) during the assays. To this end, $5 \mathrm{~g}$ of pellets for each diet were suspended in $200-\mathrm{mL}$ flasks containing saline water (salinity $25 \%$ o), gently shaken (30 r.p.m.) at $28^{\circ} \mathrm{C}$ to simulate the fluidodynamic conditions in the bottom of the feeding tanks. After $3 \mathrm{~h}$, the remaining suspended matter was recovered by filtering the saline solution through 1-mm mesh cloth. The retained matter was then dried at $105^{\circ} \mathrm{C}$ until constant weight was obtained.

The loss of dry matter (LDM) and loss of crude protein (LCP) during the time the diet was immersed were determined according to following equations (Cruz-Suárez et al, 2001):

$$
\% \mathrm{LDM}=\left[\left(\mathrm{DW}_{\mathrm{i}}-\mathrm{DW}_{\mathrm{f}}\right) / \mathrm{DW}_{\mathrm{i}}\right] \times 100
$$

where $\mathrm{DW}_{\mathrm{i}}$ and $\mathrm{DW}_{\mathrm{f}}$ stand for the dry weight of the feed before and after immersion, respectively. The loss of crude protein was obtained from the percentage of crude protein for the dried feed at the beginning of the experiment (noted as $\% \mathrm{P}_{\mathrm{i}}$ ) and that for the remaining feed after immersion (also in a dry basis), noted as $\% \mathrm{P}_{\mathrm{f}}$.

$$
\% \text { LCP }=\left[\% \mathrm{P}_{\mathrm{i}} \times 100-\% \mathrm{P}_{\mathrm{f}} \times(100-\% \mathrm{LDM})\right] / \% \mathrm{P}_{\mathrm{i}}
$$

The feed intake of shrimps during the assays was estimated by the difference between the dry weight of feed initially supplied and the dry weight of uneaten feed remaining in the feeding trays after the 3 hours assay. This difference was divided by the number of shrimps per tank, thus obtaining the Feed Intake factor FI (Refstie et al., 2004). This parameter was corrected to deduct the loss of dry matter during immersion, according to the equation:

$$
\mathrm{FI}_{\mathrm{adj}}=\mathrm{FI} \times(1-\mathrm{LDM} / 100)
$$

The feed intake of shrimps was related to their absolute weight gain (AWG) by means of the Feed Conversion Ratio (Hernández et al., 2008).

$$
\mathrm{FCR}=\mathrm{Fl}_{\mathrm{adj}} /(\mathrm{AWG})
$$


Finally, the Protein Efficiency Ratio (PER) was calculated as the mass of absolute weight gain per mass of protein consumed.

PER=AWG / [Protein Intake $\times(1-\mathrm{LCP} / 100)]=$ AWG / [FI $\left.\times \mathrm{P}_{\mathrm{i}} \times(1-\mathrm{LCP} / 100)\right]$

\subsection{Chemical analyses}

The proximate composition of the raw material and the experimental diets was determined according to the official methods recognized by the Association of the Official Analytical Chemists (AOAC).

Moisture and mineral content were determined gravimetrically by heating the samples at $105^{\circ} \mathrm{C}$ and $600^{\circ} \mathrm{C}$, respectively (AOAC, 1990). Crude protein content was calculated by the Kjeldahl method, employing a conversion factor of 6.25. The lipids were extracted and quantified according to the method described by Folch et al. (1957). Crude fibre content was established as the organic residue remaining after sequential treatment of samples with acid and alkali (AOAC, 1990).

Nitrogen-free extract (NFE) was calculated by difference from its proximate composition, according to the equation (Sudaryono et al., 1996):

$$
\% \text { NFE = } 100-(\% \text { protein }+\% \text { lipid }+\% \text { ash }+\% \text { crude fibre })
$$

Amino acid composition was determined according to a previous study (Kechaou et al., 2009). The samples were hydrolyzed with $200 \mu \mathrm{L}$ of $6 \mathrm{~N} \mathrm{HCl}$ under a nitrogen atmosphere at $118{ }^{\circ} \mathrm{C}$ for $18 \mathrm{~h}$. Then, the samples were completely dried under a nitrogen atmosphere and subsequently diluted by adding $2.5 \mathrm{~mL}$ water. The amino acid analysis was performed using the EZ:faast ${ }^{\mathrm{TM}}$ procedure (Phenomenex, USA) consisting of a solid phase extraction step followed by derivatization and liquid/liquid extraction. An aliquot from the organic phase was analysed on a GC-FID system (Perkin Elmer Autosystem XL).

The molecular weight distribution of peptides in the hydrolysates was analysed by gel filtration chromatography (Nguyen et al., 2011). The molecular weight fractions were separated using a highperformance liquid chromatography (HPLC) system equipped with a size exclusion column (Superdex Peptide 10/300 GL, GE Healthcare UK Ltd, Chalfont, UK). The mobile phase consisted of water with trifluoroacetic acid $0.1 \%$ and acetonitrile $0.5 \%(70: 30)$, the flow rate was $0.5 \mathrm{~mL} / \mathrm{min}$. Chromatography was monitored by measuring the absorbance at $214 \mathrm{~nm}$. The column was calibrated with standards: ribonuclease A (13 $700 \mathrm{Da})$, aprotinin (6500 Da), renin (1760 Da), vasopressine (1084 $\mathrm{Da})$ and leucine (294 Da). The molecular weight ranges of the different fractions were based on the retention times of the collected fractions and determined from a standard curve.

\subsection{Statistical analyses}

A statistical program (SPSS, SPSS Inc., Chicago, IL, USA) was used for data processing and statistical analysis. Data were subjected to analysis of variance (ANOVA). The Duncan's multiple range test is a multiple comparison procedure which was used to determine if significant differences existed between treatment means (Tang et al., 2008). Differences in treatment means were considered significant at $\mathrm{P}<0.05$. 


\section{Results}

\subsection{Dietary protein ingredients}

As shown in Table 1, the soluble protein powders have the highest protein content (87.1- $88.2 \%)$, followed by the tuna head meal (63.4\%), the insoluble protein powders (52.5 - 59.1\%) and the mixtures of protein powders (less than $50 \%$ ). With regard to the lipid content, the order was reversed, since the highest lipid content was found in the mixtures of protein powders (more than $40 \%$ ), followed by the insoluble protein powders (about 30\%), the tuna head meal (12\%) and finally soluble protein powders (slightly more than 1\%). At least, regarding the ash content, tuna head meal was found to be the richest (more than 21\%), whereas the ash content for the hydrolysates was nearly three times lower.

Molecular weight distributions of peptides of the three soluble protein powders S2, S3 and S6 are presented on the Figure 1. According to this figure, no big differences were observed whatever the hydrolysis time length as all the three hydrolysates have 63 to $67 \%$ of their peptides under 2000Da.

\subsection{Experimental diets}

Diets were formulated to contain similar protein (close to 40\%), as shown in Table 3 , while the proportions of lipids and ashes were variable. Regarding the lipid content three levels were observed: $7 \%$ (control, DS and commercial diet), 11-14\% (DI) and 19-21\% (DM). Only two levels for the ash proportion can be distinguished: $10 \%$ for the 9 experimental feeds formulated from proteolysis experiments and around 14\% for the control and commercial diets. Only the crude fiber contents didn't change whatever the feeds (2-2.3\%). The total amino acid content of the 11 diets ranged from 30 to $33 \mathrm{~g} / 100 \mathrm{~g}$, as shown in Table 4 . The essential amino acid content varied within a narrow range (16.5$17.8 \mathrm{~g} / 100 \mathrm{~g})$ and contributed to more than half (54-55\%) of the total amino acids quantified.

\subsection{Stability of the diets in seawater}

The loss of dry matter and crude protein for the 11 diets is shown in the Table 5 . After 3 hours of immersion, the diets DI presented the highest stability in water, as well as the commercial diet of reference. The diets DS exhibited lower water stability, while the largest losses of dry matter and crude protein were observed for the diets of type DM.

\subsection{Survival rate}

Shrimps were fed with eleven diets during 6 weeks. Shrimp'survival after this feeding period, ranged from 82.2 to $97.8 \%$. Highest survival rates were obtained for the groups fed with DS diets, with value higher than $96.7 \%$ of survival. On the contrary, lowest survival rates were observed when shrimps were fed with diets of type DM (82.2\% for DM2, 83.3\% for DM3). DI type of feed were found to be intermediate with survival rate value up to $90 \%$.

\subsection{Weight gain}

The 11 groups of shrimps presented an initial average weight of $4.34 \pm 0.08 \mathrm{~g}$ and attained a final weight ranging from 8.55 to $10.44 \mathrm{~g}$, as shown in the Table 6 . The absolute weight gain appeared to be significantly influenced by the type of diet. Indeed, the diets containing soluble protein powders (DS) have led to the highest values of weight gain (5.78 to $6.22 \mathrm{~g}$ ), followed by the diets type DI (5.29 
to 5.71 ) and the diets type DM (4.15 to 5.07). The poorest weight gain was observed in the shrimps fed with the diet DM2 (4.15 g).

The time of hydrolysis significantly influenced the weight gain. Indeed the longer the proteolysis was, the higher the weight gain was for DS and DM diets. However, this was the opposite for the DI diets. Compared to the commercial diet, four experimental diets (DS2, DS3, DS6 and DI2) have led to at least the same weight gain, or even higher with the DS6 feed.

With regard to the relative weight gain, related to the initial mean weight of the shrimps, significant differences between the diets were observed (Table 6). Indeed, DM2 and DM3 groups except, all the others presented equal or better relative weight gains than the one obtained with the control diet. Moreover, DS2 and DI2 were able to lead to similar relative weight gain to the commercial diet (134\%) while DS3 and DS6 have given better results (up to 147\%). The influence of the hydrolysis time on the relative weight gain was clearly evidenced. Indeed, a positive relation between the duration of hydrolysis and the relative weight gain was observed for the diets containing the soluble protein powders or the mixtures of protein powders (DS6 > DS3 > DS2 and DM6 > DM3 > DM2). In contrast, the relationship between time of hydrolysis and relative weight gain was found to be negative in the case of diets containing insoluble protein powders (DI2 > DI3 > DI6).

\subsection{Feed conversion ratio (FCR)}

The adjusted value of feed intake $\left(\mathrm{Fl}_{\mathrm{adj}}\right)$ and the feed conversion ratios (FCR) of shrimps fed with the experimental diets are shown in the Table 6 . After 6 weeks of experiment, the feed conversion ratios ranged from 1.72 to 2.22 for the nine diets containing hydrolysates. All of those diets (DM2 and DM3 excepted) have led to a better conversion rate than the one observed for the control (2.01). No clear relationship between this conversion ratio and hydrolysis' duration has been observed except for DM diets.

\subsection{Protein efficiency ratio}

The protein efficiency ratios of the experimental diets are presented in the Table 6 . The highest protein efficiency ratios were obtained by using the soluble powders (DS, from 1.46 to 1.48) followed by a group containing the insoluble powders (DI, from 1.32 to 1.37) and at least the mixed proteins powders (DM, from 1.15 to 1.26). DM feed excepted, all have allowed similar or higher protein efficiency ratio than the control diet (1.27). In addition, the feed formulated by using the soluble proteins (DS) were found better on this parameter than the commercial diet (1.33).

All the results of this study indicated that the control diet formulated with tuna head meal had an effect on growth and survival of shrimps similar to that provided by the commercial diet except for the relative weight gain which was statistically lower.

Whatever the studied parameters and according to the statistical comparison procedure, the diets containing the soluble protein powders (DS2, DS3 and DS6) were found at least equivalent and sometimes superior to the commercial diet. With regard to the diets containing insoluble protein powder, the diet DI2 was found to be statistically equivalent to the commercial diet. However, the diet DI3 was detrimental in terms of relative weight gain and the diet DI6 resulted in lower survival rates. Finally, the zootechnical performance (i.e. survival rate, weight gain, feed conversion ratio and protein efficiency ratio) of the diets formulated with mixture of protein powders was significantly worse than that of commercial diet. 


\subsection{Chemical composition of shrimp muscle}

The proximate composition of shrimp muscle at the beginning and the end of experiment is showed in the Table 7. For all diets, the protein content in the muscle of shrimp increased in the course of the feeding trial. The shrimps fed with the diets of type DS presented the highest protein content in muscle. For all the other diets (DI2, DI3, DI6, DM2, DM3, DM6, CD and RD) no significant difference in protein content of shrimp muscle was observed. With regard to the lipid and mineral content, both showed an increasing trend during the 6 weeks of feeding.

\section{Discussion}

It has been established that the survival and the growth of shrimps are strictly related to the quality of the distributed feed and, in particular, to the protein source (Cruz-Suárez et al., 1992; Sudaryono et al., 1995; Sudaryono et al., 1996; Cahu and Zambonino-Infante, 2001 ). Regarding the survival rates of shrimps at the end of the trial, it was found to be relatively high (more than $82 \%$ ), indicating that the nutritive requirements for shrimp were satisfied by all these diets. Regarding this parameter, two experimental diets (DS3 and DS6) were found better than the control. Such results are in accordance with previous studies which revealed that the survival of the animal can be improved when fish protein hydrolysates were supplemented in the diet. For instance, Kvåle et al. (2002) reported that a survival rate of halibut larvae of $67 \%$ was obtained when their diet was enriched with $10 \%$ hydrolysates from cod and squid muscle, compared to $57 \%$ for the control diet. Similarly, the survival rate of bass larvae was increased from $39 \%$ to $47 \%$ after replacing $25 \%$ of the fish meal in their diets by a commercial fish protein hydrolysate (Cahu et al., 1999).

Regarding the growth of shrimps, the present study demonstrate that the incorporation of the soluble protein powders (S2, S3 and S6) in the diets can significantly improve the weight gain. This has been noticed before and notably the fact that the incorporation of fish protein hydrolysates on aquafeeds have a positive effect on the growth of salmon (Berge and Storebakken, 1996; Refstie et al., 2004). The beneficial effect of pre-hydrolysis on the utilization of dietary protein was also reported in goldfish Carassius auratus (Szlaminska et al., 1991), carp Cyprinus carpio (Carvalho et al., 1997) and yellow croaker Pseudosciaena crocea (Tang et al., 2008). This positive effect may be attributed to a better absorption efficiency of the hydrolysates (Cissé et al., 1995; Ouellet et al., 1997). However, it has to be noticed that all those hydrolysates have been produced under mild procedures in order to preserve their nutritional, functional and organoleptic characteristics. Furthermore, free amino acid and small molecular weight compounds released during the hydrolysis might also act as feed attractants for shrimps, increasing both feed intake and weight gain (Hardy, 1991; Berge and Storebakken, 1996; Aksnes et al., 2006).

In contrast with DI and DS diets, the incorporation of the mixture of protein powder (M2, M3 and M6) did not only reduce the survival and growth of shrimps, but was detrimental to both. According to the proximate composition of the diets, the adverse effect of the DM diets could be attributable to their lipid content. In fact, an inverse relationship was observed between the lipid content of diet and the survival rate or weight gain. The diet DM2 had the highest lipid content $(21.1 \%$ lipid) and led to the lowest survival rate and weight gain (only $82.2 \%$ and $94.32 \%$, respectively). Akiyama et al. (1992) reported an optimum lipid content between 6 and 7.5\% for the diet of shrimps Penaeus monodon, whereas a lipid content above $10 \%$ resulted in an increase of mortality and a decline of shrimp growth. However, a dietary lipid content above $15 \%$ did not restrain the growth of shrimps Penaeus chinensis (Guillaume et al., 1999). Thus it seems the nutritional needs differ among the shrimp species, but it can be assumed that the high lipid level in the DM diets should lead to a nutritional imbalance and reduce the digestibility of the feed (Aranyakananda and Lawrence., 1994; Refstie et al., 2004). 
The growth of shrimp was affected by dietary protein source and diet quality (Rajyalakshmi et al., 1986; Sudaryono et al., 1995; Kureshy and Davis, 2002). Sudaryono et al. (1995) indicated that protein source was the major factor influencing growth rates in shrimp. The fish meal, which is employed as major protein source in aquafeeds for these species, has been replaced by other protein sources such as the crab meal (Goytortúa-Bores et al., 2006), the squid meal (Cruz-Ricque et al., 1987), the shrimp by-product meal (Cruz-Suárez et al., 1993), the fish by-product meal (Hernández et al., 2004), the poultry by-product meal (Davis and Arnold, 2000; Cruz-Suárez et al, 2007) and the fish protein hydrolysates (Córdova-Murueta and García-Carreño, 2002; Aguila et al., 2007).

Enzymatic hydrolysis of fish or fish by-products produces fish protein hydrolysates (FPH) rich in soluble low molecular weight peptides (Liaset et al., 2000). Some previous studies have demonstrated that the survival and growth of fish larvae may be related to the molecular weight of peptides in the protein hydrolysate added to feed. Thus, the role of dietary short peptides on larvae development has been investigated by several authors. For instance, Zambonino-Infante et al. (1997) showed that the replacement of $20 \%$ of the fish meal in diet by di-and tri-peptides (obtained from hydrolysis of fish meal) improved both growth and survival of sea bass (Dichentrarchus labrax) larvae. This can be explained by the fact that the low molecular weight of these peptides favors their assimilation by the body (Espe et al., 1993). However, Carvalho et al. (2004) remarked that the supplementation of di-and tri-peptides above an upper limit was detrimental for the culture of carp larvae in early feeding stages. An improvement in the survival rate was observed when the diets were supplemented with hydrolysates rich in medium-chain peptides (Cahu and Zambonino Infante, 1995). Hydrolysates containing a major part of the peptides within the 500-2500 Da range were found to promote the growth of sea bass larvae better than where the peptides between 200 and 500 Da were predominant (Kotzamanis et al., 2007). In our study, the molecular weight profiles for the three hydrolysates S2, S3 and S6 were similar, which can partially explain the lack of significant differences found in survival rate, feed conversion ratio and protein efficiency ratio for the diets DS2, DS3 and DS6. However, slight discrepancies can be observed. The amount of peptides bigger than 7000Da decreased with time of hydrolysis (15\% after $2 \mathrm{~h}$ of proteolysis, $11 \%$ after $6 \mathrm{~h}$ ) while the proportion of free amino acids and dipeptides increased (17\% below 250Da after $2 \mathrm{~h}$ of proteolysis, 19\% after $6 \mathrm{~h}$ ).

Four of 9 diets containing hydrolysates (DS2, DS3, DS6 and DI2) improved the feed conversion ratio of the diets, compared to the control diet. These results confirmed those obtained by Córdova-Murueta and García-Carreño (2002) where the supplementation of 4, 12, 20\% fish protein hydrolysates in the diet of the shrimp Panaeus vannamei resulted in an improvement of feed conversion ratios $(2.6 ; 2.6$ and 2.9 respectively compared to 3.2 for the control diet).

Protein efficiency ratio (PER) is commonly considered as a good criterion to evaluate protein quality for aquatic feed. In our study, given that the dietary protein content was similar among the nine experimental diets, the differences between the PER values indicate a different protein quality in the feeds. The role of dietary free amino acids on growth of animal has been extensively discussed for larvae at early stages of growth, due to their inability to degrade the ingested protein (Ronnested et al., 1999). Besides their nutritional function, free amino acids may play a very important role in first feeding by acting as chemo-attractants (Cahu and Zambonino-Infante, 2001). In the present study, the analysis of amino acid composition of the diets revealed that not all the essential amino acids were sufficiently provided by the diets. Nevertheless, the shrimps presented high survival rates and experienced weight gain during the six weeks of the experiment. Therefore, it is difficult to state that amino acid deficiency could be harmful to the shrimp growth and survival. The lower values of PER (diets type DM) corresponded with the highest lipid levels, which was in agreement with the results reported by $\mathrm{Hu}$ et al. (2008), who showed the inefficient conversion of protein to the presence of high dietary lipid levels in shrimp Litopenaeus vannamei. 
On the basis of the above mentioned results, it can be concluded that the resulting fractions after conducing a proteolysis have to be separated in order to recover the soluble proteins for aquafeed formulating.

The shrimps fed with the diets of type DS presented the highest protein content in muscle. This could be related to a higher protein synthesis in those shrimps fed with better dietary protein sources (Córdova-Murueta et García-Carreño, 2002).

\section{Conclusions}

The present study showed that the diets supplied with soluble protein powders (DS2, DS3 and DS6), as well as one containing insoluble protein powder (DI2) from the hydrolysis of tuna head improved significantly both growth and the survival rates of shrimps, as well as the feed conversion ratio and the protein efficiency ratio. On the contrary, the incorporation of the mixtures of protein powder did not improve the survival and growth of shrimp, compared with the control. The results demonstrated that the hydrolysis of the tuna heads and the ulterior separation of the resulting fractions by centrifugation had a positive effect on the survival and growth of shrimps, compared to the traditional feeding with fish meal. Further research is needed in order to develop a commercial diet containing fish hydrolysates. The scaling up of the procedure described above requires that all the operational variables controlling the hydrolysis be optimized in order to assure the quality standards of a product intended to shrimp feeding while limiting the operation costs associated (i.e. energy consumption, time of hydrolysis, etc).

\section{Acknowledgements}

The authors are grateful to the seafood processing company 'Hai Vuong' in Vietnam for providing the raw materials for this research.

This study is part of the actions conduced by the members of the SEA ${ }^{\text {PRO }}$ network (www.seapro.fr) which aims to promote a better use of the marine biomass with sustainable process.

\section{References}

1. Aguila, J., Cuzon, G., Pascual, C., Domingues, P.M., Gaxiola, G., Sanchez, A., Maldonado, T., Rosas,C., 2007. The effects of fish hydrolysate (CPSP) level on Octopus maya (Voss and Solis) diet: Digestive enzyme activity, blood metabolites, and energy balance. Aquaculture 273(4), 641655.

2. Akiyama, D.M., Dominy, W.G., Lawrence, A.L., 1992. Penaeid shrimp nutrition. In: Fast A.W., Lester L.J. (Eds). Marine Shrimp Culture: Principles and Practices. Developments in aquaculture and fisheries science, Elsevier 23, 535-568.

3. Aksnes, A., Hope, B., Jönsson, E., Björnsson, B.T., Albrektsen, S., 2006. Size-fractionated fish hydrolysate as feed ingredient for rainbow trout (Oncorhynchus mykiss) fed with high plant protein diets. I: Growth, growth regulation and feed utilization. Aquaculture 261, 305-317. 
4. Anggawati, A.M., Murtini, J.T., Heruwati, E.S., 1990. The use of hydrolyzed protein concentrate in practical diets for Penaeus monodon juveniles. Research Report. Research Institute for Fish Technology. Palmerah Jakarta, $12 \mathrm{pp}$.

5. AOAC, 1990. Official Method of Analysis, 15th ed. Arlington, VA: Association of Official Analytical Chemists.

6. Aranyakananda, P., Lawrence, A.L., 1994. Effects of ingestion rate on dietary protein and energy requirements of Penaeus vannamei and the optimal protein to energy ratio. Memorias 2 Simposio en Nutricion Acuicola. Monterrey, México, 1-19.

7. Berge, G.M., Storebakken, T., 1996. Fish protein hydrolysate in starter diets for Atlantic salmon (Salmo salar) fry. Aquaculture 145(1-4), 205-212.

8. Cahu, C.L., Zambonino-Infante, J.L., 1995. Maturation of pancreatic and intestinal digestive functions in sea bass (dicentrarchus labrax): Effect of weaning with deferent protein sources. Fish Physiol. Biochem. 14, 431-437.

9. Cahu, C.L., Zambonino-Infante, J.L., 2001. Substitution of live food by formulated diets in marine fish larvae. Aquaculture 2001, 161-180.

10. Cahu, C.L., Zambonino-Infante, J.L., Quazuguel, P., Le Gall, M.M., 1999. Protein hydrolysate vs. fish meal in compound diets for 10-day old sea bass Dicentrarchus labrax larvae. Aquacuture 171(1-2), 109-119.

11. Carvalho, A.P., Escaffre, A.M., Oliva Teles, A., Bergot, P., 1997. First feeding of common carp larvae on diets with high levels of protein hydrolysates. Aquacult Inter. 5, 361-367.

12. Carvalho, A.P., Sá,R., Oliva-Teles, A., Bergot, P., 2004. Solubility and peptide profile affect the utilization of dietary protein by common carp (Cyprinus carpio) during early larval stages. Aquaculture 234 (1-4), 319-333.

13. Cissé, A., Luquet, P., Etchian, A., 1995. Utilisation par Chrysichthys nigrodigitatus (Bagridae) d'ensilage chimique ou biologique de poisson. Aquat. Living Resour. 8, 373-377.

14. Córdova-Murueta, J.H., García-Carreño, F.L., 2002. Nutritive value of squid and hydrolyzed protein supplement in shrimp feed. Aquaculture 210 (1-4), 371-384.

15. Cruz-Ricque, L.E., Guillaume, J., Cuzon, G., 1987. Squid protein effect on growth of four penaeid shrimp. World Aquacult. Soc. 18, 209-217.

16. Cruz-Suárez, L.E., Nieto-López, M., Guajardo-Barbosa, C., Tapia-Salazar, M., Scholz, U., RicqueMarie, D., 2007. Replacement of fish meal with poultry by-product meal in practical diets for Litopenaeus vannamei, and digestibility of the tested ingredients and diets. Aquaculture 272 (1-4), 466-476.

17. Cruz- Suárez, L.E., Ricque, D., Aquacop., 1992. Effect of squid meal on growth of Penaeus monodon juveniles reared in pond pens and tanks. Aquaculture 106, 293-299.

18. Cruz-Suárez, L.E., Ricque-Marie, D., Martinez-Vega, J.A., Wesche-Ebeling, P., 1993. Evaluation of two shrimp by-product meals as protein sources in diets for Penaeus vannamei. Aquaculture 115 (1-2), 53-62.

19. Cruz-Suárez, L.E., Ricque-Marie, D., Tapia-Salazar, M., McCallum, I.M., Hickling, D., 2001. Assessment of differently processed feed pea (Pisumsativum) meals and canola meal (Brassica sp.) in diets for blue shrimp (Litopennaeus stylirostris). Aquaculture 196, 87-104.

20. Davis, A.D., Arnold, C.R., 2000. Replacement of fish meal in practical diets for the Pacific white shrimp, Litopenaeus vannamei. Aquaculture 185(3), 291-298.

21. Day, O.J., Howell, B.R., Jones, D.A., 1997. The effect of dietary hydrolyzed fish protein concentrate on the survival and growth of juvenile Dover sole, Solea solea (L.), during and after weaning. Aquacult. Res. 28, 911-921.

22. Espe, M; Liet, E., Torrissen, K.R., 1993. Changes in plasma and muscle free amino acids in Atlantic salmon (Salmo salar) during absorption of diets containing different amounts of hydrolysed cod. Comp. Biochem. Physiol. 105(3), 555-562.

23. Folch, J., Lees, M., Sloan-Standley, G.H., 1957. A simple method for the isolation and purification of total lipids from animal tissues. J. Biol. Chem. 226, 497-509.

24. Goytortúa-Bores, E., Civera-Cerecedo, R., Rocha-Meza, S., Green-Yee, A., 2006. Partial replacement of red crab (Pleuroncodes planipes) meal for fish meal in practical diets for the white 
shrimp Litopenaeus vannamei. Effects on growth and in vivo digestibility. Aquaculture 256 (1-4), 414-422.

25. Guillaume, J., Kaushik, S., Bergot, P., Métailler, R., 1999. Nutrition et alimentation des poissons et crustacés. INRA, IFREMER, France, 489pp.

26. Hardy, R.W., 1991. Fish hydrolysates: production and use in aquaculture feeds. In: Akiyama,D.M., Tan, R.K.H (Eds.). Proceeding of the Aquaculture Feed Processing and Nutrition Workshop. American Soybean Association, Singapore, 109-115.

27. Hernández, C., Olvera-Novoa, M.A., Aguilar-Vejar, K., González-Rodríguez, B., Abdo de la Parra, I. 2008. Partial replacement of fish meal by porcine meat meal in practical diets for Pacific white shrimp (Litopenaeus vannamei). Aquaculture 277, 244-250.

28. Hernández, C., Sarmiento-Pardo, J., González-Rodríguez, B., Abdo Parra de la I., 2004. Replacement of fish meal with co-extruded wet tuna viscera and corn meal in diets for white shrimp (Litopenaeus vannamei Boone). Aquaculture 35, 1153-1157.

29. Hu, Y., Tan, B., Mai, K., Ai, Q., Zheng, S., Cheng, K., 2008. Growth and body composition of juvenile white shrimp, Litopenaeus vannamei, fed different ratios of dietary protein to energy. Aquaculture Nutrition 14, 499-506.

30. Kechaou, E.S., Dumay, J., Donnay-Moreno, C., Jaouen, P., Gouygou, J.P., Bergé, J.P., Amar, R.B., 2009. Enzymatic hydrolysis of cuttlefish (Sepia officinalis) and sardine (Sardina pilchardus) viscera using commercial proteases: Effects on lipid distribution and amino acid composition. J. Biosci. Bioeng. 107, 158-164.

31. Klompong, V., Benjakul, S., Kantachote, D., Shahidi, F., 2007. Antioxidative activity and functional properties of protein hydrolysate of yellow stripe trevally (Selaroides leptolepis) as influenced by the degree of hydrolysis and enzyme type. Food Chem. 102, 1317-1327.

32. Kotzamanis, Y.P., Gisbert, E., Gatesoupe, F.J., Zambonino Infante, J., Cahu, C., 2007. Effects of different dietary levels of fish protein hydrolysates on growth, digestive enzymes, gut microbiota, and resistance to Vibrio anguillarum in European sea bass (Dicentrarchus labrax) larvae. Comparative biochem and physiol. 147, 205-214.

33. Kristinsson, H.G, Rasco, B.A., 2000., Biochemical and functional properties of Atlantic salmon (Salmo salar) muscle proteins hydrolyzed with various alkaline proteases. Agri. Food Chem. 48, 657-66.

34. Kureshy, N., Davis, D.A., 2002. Protein requirement for maintenance and maximum weight gain for the Pacific white shrimp, Litopenaeus vannamei. Aquaculture 204, 125-143.

35. Kvåle, A., Harboe, T., Espe, M., Næss T., Hamre K., 2002. Effect of predigested protein on growth and survival of Atlantic halibut larvae (Hippoglossus hippoglossus L.). Aquac. Res. 33(5), 311-321.

36. Liaset, B., Lied, E., Espe, M., 2000. Enzymatic hydrolysis of by-products from the fish-filleting industry; chemical characterisation and nutritional evaluation. J. Sci Food Agric. 80, 581-589.

37. Nguyen, H.T.M., Sylla, K.S.B., Randriamahatody, Z., Donnay-Moreno, C., Moreau, J., Tran, L.T., Bergé, J.P., 2011. Enzymatic hydrolysis of yellowfin tuna (Thunnus albacares) by-products using Protamex protease. Food Technol. Biotechnol. 49 (1), 48-55.

38. Ouellet, D.R., Seoane, J.R., Veira, D.M., Proulx, J.G., 1997. Effects of supplementation with fish meal or fish protein hydrolysate on growth, nutrient digestibility and rumen fermentation of growing cattle fed grass silage. Animal Feed Sci Technol. 68, 307-326.

39. Rajyalakshmi, T., Pillai, S.M., Roy, A.K., Verghese, P.U., 1986. Feeds and nutrition of the prawn Penaeus monodon. Environ. Ecol. 4, 415-22.

40. Refstie, S., Olli, J.J., Standal, H., 2004. Feed intake, growth and protein utilization by post-smolt Alantic salmon (Salmo salar) in response to graded levels of fish protein hydrolysate in the diet. Aquaculture 239, 331-349.

41. Ronnestad, I., Thorsen, A., Finn, R.N., 1999., Fish larval nutrition: a review of recent advances in the roles of amino acids. Aquaculture 177, 201-216.

42. Szlaminska, M., Escaffre, A.M., Charlon, N., Bergot, P., 1991. Preliminary data on semisynthetic diets for goldfish (Carassius auratus) larvae. In: Kaushik, S.J., Luquet, P. (Eds.). Fish Nutrition in Practice, Biarritz, France, 24-27 June 1991. INRA, Paris, Les Colloques 61, pp. 607-612. 
43. Sudaryono, A., Hoxey, M.J., Kailis, S.G., Evans, L.H., 1995. Investigation of alternative protein sources in practical diets for juvenile shrimp, Penaeus monodon. Aquaculture 134, 313-23.

44. Sudaryono, A., Tsvetnenko, E., Evans, L.H., 1996. Digestibility studies on fisheries by-product based diets for Penaus monodon. Aquaculture 143, 331-340.

45. Tacon, A.G.J., Metian, M., 2008. Global overview on the use of fish meal and fish oil in industrially compounded aquafeeds: Trends and future prospects. Aquaculture 285, 146-158.

46. Tang, H.G., Wu, T.X., Zhao, Z.Y., Pan, X.D., 2008. Effects of fish protein hydrolysate on growth performance and humoral immune response in large yellow croaker (Pseudosciaena crocea R.). Zhejiang Univ Sci B. 9, 684-690.

47. Thiansilakul, Y., Benjakul, S., Shahidi, F., 2007. Composition, functional properties and antioxidative activity of protein hydrolysates prepared from round scad (Decapterus maruadsi). Food Chem. 103, 1385-1394.

48. Zambonino-Infante, J.L., Cahu, C.L., Péres, A., 1997. Partial substitution of di-and tripeptides for native proteins in sea bass diet improves Dicentrarchus labrax larval development. J. Nutr. 127, 608-614.

Tables

Table 1. Proximate composition of the dietary protein ingredients (\% dry matter).

\begin{tabular}{lcrc}
\hline $\begin{array}{l}\text { Dietary protein ingredients } \\
\text { (\% dry matter) }\end{array}$ & Protein & Lipid & Ash \\
\hline Tuna head meal & $63.4 \pm 0.8$ & $12.3 \pm 0.4$ & $21.3 \pm 0.1$ \\
Fish protein powder S2 & $87.1 \pm 0.8$ & $1.4 \pm 0.3$ & $8.6 \pm 0.3$ \\
Fish protein powder S3 & $87.7 \pm 0.7$ & $1.3 \pm 0.2$ & $8.2 \pm 0.4$ \\
Fish protein powder S6 & $88.2 \pm 0.9$ & $1.4 \pm 0.3$ & $8,3 \pm 0.4$ \\
Fish protein powder I2 & $59.1 \pm 0.4$ & $28.4 \pm 0.6$ & $7.1 \pm 0.1$ \\
Fish protein powder I3 & $57.0 \pm 0.6$ & $29.9 \pm 0.5$ & $7.2 \pm 0.2$ \\
Fish protein powder 16 & $52.5 \pm 0.8$ & $33.7 \pm 0.3$ & $7.4 \pm 0.1$ \\
Fish protein powder M2 & $44.4 \pm 0.7$ & $44.8 \pm 0.5$ & $7.5 \pm 0.2$ \\
Fish protein powder M3 & $45.7 \pm 0.4$ & $44.5 \pm 0.6$ & $7.4 \pm 0.2$ \\
Fish protein powder M6 & $47.9 \pm 0.9$ & $43.5 \pm 0.4$ & $7.0 \pm 0.3$ \\
Soybean meal & $43.5 \pm 0.4$ & $3.4 \pm 0.2$ & $7.4 \pm 0.4$ \\
Rice bran & $12.6 \pm 0.7$ & $9.8 \pm 0.3$ & $11.9 \pm 0.5$ \\
Wheat & $14.4 \pm 0.5$ & $1.8 \pm 0.3$ & $1.0 \pm 0.1$ \\
\hline
\end{tabular}

Values reported are means of three replicates. 
Table 2. Ingredients of the experimental diets (\% dry matter)

\begin{tabular}{lcccccccccc}
\hline $\begin{array}{l}\text { Ingredients of the diets } \\
\text { (\% dry matter) }\end{array}$ & CD & DS2 & DS3 & DS6 & DI2 & DI3 & DI6 & DM2 & DM3 & DM6 \\
\hline Tuna head meal & 44.6 & 22.3 & 22.3 & 22.3 & 22.3 & 22.3 & 22.3 & 22.3 & 22.3 & 22.3 \\
Fish protein powder S2 & 0 & 15.4 & 0 & 0 & 0 & 0 & 0 & 0 & 0 & 0 \\
Fish protein powder S3 & 0 & 0 & 15.3 & 0 & 0 & 0 & 0 & 0 & 0 & 0 \\
Fish protein powder S6 & 0 & 0 & 0 & 15.2 & 0 & 0 & 0 & 0 & 0 & 0 \\
Fish protein powder I2 & 0 & 0 & 0 & 0 & 24.4 & 0 & 0 & 0 & 0 & 0 \\
Fish protein powder I3 & 0 & 0 & 0 & 0 & 0 & 25.6 & 0 & 0 & 0 & 0 \\
Fish protein powder I6 & 0 & 0 & 0 & 0 & 0 & 0 & 28.7 & 0 & 0 & 0 \\
Fish protein powder M2 & 0 & 0 & 0 & 0 & 0 & 0 & 0 & 36.9 & 0 & 0 \\
Fish protein powder M3 & 0 & 0 & 0 & 0 & 0 & 0 & 0 & 0 & 34.9 & 0 \\
Fish protein powder M6 & 0 & 0 & 0 & 0 & 0 & 0 & 0 & 0 & 0 & 32.6 \\
Soybean meal & 15 & 15 & 15 & 15 & 15 & 15 & 15 & 15 & 15 & 15 \\
Rice bran & 10 & 10 & 10 & 10 & 10 & 10 & 10 & 10 & 10 & 10 \\
Wheat & 27.4 & 32.3 & 32.4 & 32.5 & 25.3 & 24.1 & 21.0 & 12.8 & 14.8 & 17.1 \\
Mineral and vitamin ${ }^{1}$ & 3 & 3 & 3 & 3 & 3 & 3 & 3 & 3 & 3 & 3 \\
Squid oil & 0 & 2 & 2 & 2 & 0 & 0 & 0 & 0 & 0 & 0 \\
\hline
\end{tabular}

1. Per kg of mineral and vitamin mixture : Vitamin A :1000000 UI, Vitamin D3 : 300000 UI, Vitamin E: 2000 mg, Vitamin K3 : 500 mg, Vitamin B1: 500 mg, Vitamin B2: 320 mg, Niacine: 2000 mg, Vitamin B6 : 500 mg, Inositol: 10000 mg, Biotine :20mg, Folic acid : $200 \mathrm{mg}$, D-Calpan:2500 mg, Vitamin B3 : 5mg, Vitamin B12 : $5 \mathrm{mg}$, Vitamin C: 10000 mg, Phosphorus: $10000 \mathrm{mg}$, Calcium : 8000mg, Zinc :5000mg, Manganese: $2000 \mathrm{mg}$, Magnesium: $750 \mathrm{mg}$, Choline chloride: $5000 \mathrm{mg}$, Cobalt: $50 \mathrm{mg}$, Selenium : $50 \mathrm{mg}$, lodine : $20 \mathrm{mg}$.

Table 3. Proximate composition of the experimental diets (\% dry matter).

\begin{tabular}{|c|c|c|c|c|c|c|c|c|c|c|c|}
\hline & $\mathrm{CD}$ & DS2 & DS3 & DS6 & $\mathrm{DI} 2$ & DI3 & DI6 & DM2 & DM3 & DM6 & $\mathrm{RD}$ \\
\hline Dry matter (DM) (\%) & 90.6 & 90.5 & 90.7 & 91.2 & 90.8 & 91.1 & 90.4 & 90.8 & 91.1 & 91.4 & 90.1 \\
\hline Com & & & & & & & & & & & \\
\hline Crude protein & 40.0 & 40.1 & 40.2 & 40.0 & 40.1 & 39.8 & 40.2 & 39.8 & 40.0 & 40.2 & 40.0 \\
\hline Lipid & 7.5 & 7.0 & 7.1 & 7.1 & 11.5 & 12.3 & 14.2 & 21.1 & 20.0 & 18.8 & 6.8 \\
\hline Ash & 13.8 & 10.2 & 10.1 & 10.2 & 10.4 & 10.6 & 10.8 & 10.7 & 10.4 & 10.1 & 14.2 \\
\hline Crude fiber & 2.2 & 2.3 & 2.3 & 2.3 & 2.2 & 2.2 & 2.1 & 2.0 & 2.0 & 2.1 & 2.3 \\
\hline Nitrogen-free extract & 36.5 & 40.4 & 40.3 & 40.4 & 35.8 & 35.1 & 32.7 & 26.4 & 27.6 & 28.8 & 36.7 \\
\hline
\end{tabular}

Values reported are means of three replicates. 
Table 4. Amino acid composition of the experimental diets (\% dry matter)

\begin{tabular}{|c|c|c|c|c|c|c|c|c|c|c|c|c|}
\hline $\begin{array}{l}\text { Amino acids } \\
\text { (\% dry matter) }\end{array}$ & $\mathrm{R}$ * & $C D$ & DS2 & DS3 & DS6 & $\mathrm{DI} 2$ & DI3 & DI6 & DM2 & DM3 & DM6 & $\mathrm{RD}$ \\
\hline \multicolumn{13}{|l|}{ EAA } \\
\hline Arginine & 2.32 & 1.77 & 2.08 & 2.03 & 1.85 & 1.74 & 1.8 & 1.88 & 1.98 & 2.01 & 1.98 & 2.05 \\
\hline Histidine & 0.84 & 0.91 & 0.95 & 0.94 & 0.93 & 0.88 & 0.90 & 0.88 & 0.89 & 0.94 & 0.98 & 0.91 \\
\hline Isoleucine & 1.4 & 1.60 & 1.70 & 1.60 & 1.56 & 1.65 & 1.59 & 1.28 & 1.33 & 1.66 & 1.79 & 1.66 \\
\hline Leucine & 2.16 & 2.88 & 2.86 & 2.60 & 2.70 & 2.72 & 2.24 & 2.39 & 2.40 & 2.40 & 2.29 & 2.59 \\
\hline Lysine & 2.12 & 2.37 & 2.12 & 2.16 & 2.35 & 2.97 & 3.02 & 3.24 & 2.15 & 1.94 & 1.91 & 1.98 \\
\hline Methionine & 0.96 & 0.75 & 0.74 & 0.73 & 0.80 & 0.66 & 0.80 & 0.84 & 0.55 & 0.70 & 0.71 & 0.72 \\
\hline Phenylalanine & 1.6 & 2.22 & 2.50 & 3.27 & 3.00 & 2.78 & 2.88 & 2.46 & 3.2 & 2.81 & 2.65 & 2.74 \\
\hline Threonine & 1.44 & 2.80 & 2.8 & 2.78 & 2.79 & 2.51 & 2.44 & 2.22 & & 2.6 & 3.1 & 3.09 \\
\hline Valine & 1.6 & 1.45 & 1.68 & 1.74 & 1.74 & 1.42 & 1.47 & 1.62 & 1.48 & 1.45 & 1.63 & 1.59 \\
\hline Total EAA & & 16.75 & 17.45 & 17.85 & 17.72 & 17.33 & 17.14 & 16.81 & 16.51 & 16.52 & 17.05 & 17.33 \\
\hline \multicolumn{13}{|l|}{ NEAA } \\
\hline Alanine & & 3.36 & 3.80 & 3.88 & 3.74 & 3.96 & 3.91 & 3.63 & 3.56 & 3.46 & 3.85 & 3.44 \\
\hline Aspartic & & 0.82 & 0.81 & 0.75 & 0.92 & 0.87 & 0.93 & 0.79 & 0.84 & 0.50 & 0.48 & 1.47 \\
\hline Glutamic & & 2.38 & 1.99 & 1.57 & 1.54 & 1.56 & 1.58 & 1.55 & 1.85 & 1.61 & 1.82 & 1.31 \\
\hline Glycine & & 3.90 & 3.80 & 4.05 & & 3.26 & 2.97 & 3.21 & 3.36 & 3.78 & 3.59 & 3.88 \\
\hline Hydroxyproline & & 0.57 & 0.95 & 1.10 & 1.14 & 0.57 & 0.55 & 0.44 & 0.55 & 0.67 & 0.70 & 0.67 \\
\hline Proline & & 1.23 & 1.40 & 1.32 & 1.51 & 1.48 & 1.49 & 1.33 & 1.43 & 1.48 & 1.42 & 0.24 \\
\hline Serine & & 0.75 & 0.87 & 0.76 & 0.79 & 1.18 & 1.33 & 1.81 & 1.13 & 0.88 & 1.16 & 1.95 \\
\hline Tyrosine & & 1.21 & 1.22 & 1.51 & 1.47 & 1.21 & 1.27 & 1.33 & 1.29 & 1.28 & 1.24 & 1.22 \\
\hline Total NEAA & & 14.22 & 14.84 & 14.94 & 15.06 & 14.09 & 14.03 & 14.09 & 14.01 & 13.66 & 14.26 & 14.18 \\
\hline acids & & 30.97 & 32.29 & 32.79 & 32.78 & 31.42 & 31.17 & 30.90 & 30.52 & 30.18 & 31.31 & 31.51 \\
\hline
\end{tabular}

EAA: Essential amino acids; NEAA: Non essential amino acids.

* Recommended requirements (Akiyama et al., 1992).

Table 5. Percentages of dry matter loss and crude protein loss for the 11 diets studied.

\begin{tabular}{lcc}
\hline Diets & Dry matter loss (\%) & Crude protein loss (\%) \\
\hline CD & $8.65^{\mathrm{bc}} \pm 0.34$ & $9.91^{\mathrm{ab}} \pm 0.11$ \\
DS2 & $8.33^{\mathrm{ab}} \pm 0.40$ & $9.87^{\mathrm{ab}} \pm 0.12$ \\
DS3 & $8.29^{\mathrm{ab}} \pm 0.20$ & $9.86^{\mathrm{ab}} \pm 0.10$ \\
DS6 & $8.25^{\mathrm{ab}} \pm 0.15$ & $9.96^{\mathrm{abc}} \pm 0.25$ \\
DI2 & $8.19^{\mathrm{a}} \pm 0.17$ & $9.72^{\mathrm{a}} \pm 0.17$ \\
DI3 & $8.11^{\mathrm{a}} \pm 0.18$ & $9.73^{\mathrm{a}} \pm 0.29$ \\
DI6 & $8.16^{\mathrm{a}} \pm 0.26$ & $9.72^{\mathrm{a}} \pm 0.19$ \\
DM2 & $8.90^{\mathrm{c}} \pm 0.17$ & $10.43^{\mathrm{d}} \pm 0.20$ \\
DM3 & $8.87^{\mathrm{c}} \pm 0.16$ & $10.29^{\mathrm{cd}} \pm 0.17$ \\
DM6 & $8.80^{\mathrm{c}} \pm 0.23$ & $10.21^{\mathrm{bcd}} \pm 0.18$ \\
RD & $8.34^{\mathrm{ab}} \pm 0.17$ & $9.69^{\mathrm{a}} \pm 0.26$ \\
\hline
\end{tabular}

Values reported are means of three replicates. Mean values in the same column with different superscript letter are significantly different $(\mathrm{P}<0.05)$. 
Table 6. Values of survival rate, weight gain, adjusted feed intake, feed conversion ratio and protein efficiency ratio for the 11 diets studied.

\begin{tabular}{lcccccccc}
\hline Diets & Survival (\%) & $\begin{array}{c}\text { Initial mean } \\
\text { weight }(\mathrm{g})\end{array}$ & $\begin{array}{c}\text { Final mean } \\
\text { weight }(\mathrm{g})\end{array}$ & AWG $(\mathrm{g})$ & RWG (\%) & Fl $\mathrm{adj}_{\mathrm{g}}(\mathrm{g})$ & FCR \\
\hline CD & $92.2^{\mathrm{bcd}} \pm 1.9$ & $4.30 \pm 0.09$ & $9.46 \pm 0.09$ & $5.16^{\mathrm{c}} \pm 0.08$ & $120.09^{\mathrm{cd}} \pm 4.07$ & $10.38^{\mathrm{cde}} \pm 0.13$ & $2.01^{\mathrm{c}} \pm 0.06$ & $1.27^{\mathrm{bcd}} \pm 0.04$ \\
DS2 & $96.7^{\mathrm{de}} \pm 3.3$ & $4.31 \pm 0.11$ & $10.09 \pm 0.13$ & $5.78^{\mathrm{ef}} \pm 0.07$ & $134.18^{\mathrm{f}} \pm 3.98$ & $10.01^{\mathrm{c}} \pm 0.31$ & $1.73^{\mathrm{a}} \pm 0.03$ & $1.47^{\dagger} \pm 0.03$ \\
DS3 & $97.8^{\mathrm{e}} \pm 1.9$ & $4.27 \pm 0.05$ & $10.27 \pm 0.14$ & $6.00^{\mathrm{fg}} \pm 0.11$ & $140.63^{\mathrm{g}} \pm 1.96$ & $10.24^{\mathrm{cd}} \pm 0.20$ & $1.72^{\mathrm{a}} \pm 0.07$ & $1.48^{\dagger} \pm 0.05$ \\
DS6 & $97.8^{\mathrm{e}} \pm 1.9$ & $4.22 \pm 0.09$ & $10.44 \pm 0.13$ & $6.22^{\mathrm{g}} \pm 0.08$ & $147.38^{\mathrm{h}} \pm 3.67$ & $10.76^{\dagger} \pm 0.12$ & $1.74^{\mathrm{a}} \pm 0.03$ & $1.46^{\dagger} \pm 0.02$ \\
DI2 & $92.2^{\mathrm{bcd}} \pm 1.9$ & $4.36 \pm 0.08$ & $10.07 \pm 0.24$ & $5.71^{\mathrm{e}} \pm 0.18$ & $131.09^{\mathrm{ef}} \pm 2.71$ & $10.61^{\mathrm{ef}} \pm 0.22$ & $1.86^{\mathrm{b}} \pm 0.06$ & $1.37^{\mathrm{e}} \pm 0.05$ \\
DI3 & $90.0^{\mathrm{bc}} \pm 3.3$ & $4.35 \pm 0.08$ & $9.84 \pm 0.08$ & $5.49^{\mathrm{d}} \pm 0.12$ & $126.30^{\mathrm{de}} \pm 4.73$ & $10.43^{\mathrm{def}} \pm 0.24$ & $1.90^{\mathrm{bc}} \pm 0.03$ & $1.33^{\mathrm{de}} \pm 0.02$ \\
DI6 & $88.9^{\mathrm{b}} \pm 1.9$ & $4.35 \pm 0.07$ & $9.64 \pm 0.12$ & $5.29^{\mathrm{cd}} \pm 0.14$ & $121.38^{\mathrm{cd}} \pm 4.44$ & $10.15^{\mathrm{cd}} \pm 0.20$ & $1.92^{\mathrm{bc}} \pm 0.07$ & $1.32^{\mathrm{cde}} \pm 0.05$ \\
DM2 & $82.2^{\mathrm{a}} \pm 1.9$ & $4.40 \pm 0.04$ & $8.55 \pm 0.14$ & $4.15^{\mathrm{a}} \pm 0.11$ & $94.32^{\mathrm{a}} \pm 2.46$ & $9.21^{\mathrm{a}} \pm 0.16$ & $2.22^{\mathrm{e}} \pm 0.05$ & $1.15^{\mathrm{a}} \pm 0.02$ \\
DM3 & $83.3^{\mathrm{a}} \pm 3.3$ & $4.17 \pm 0.08$ & $8.72 \pm 0.22$ & $4.55^{\mathrm{b}} \pm 0.19$ & $109.06^{\mathrm{b}} \pm 4.73$ & $9.65^{\mathrm{b}} \pm 0.13$ & $2.12^{\mathrm{d}} \pm 0.08$ & $1.20^{\mathrm{ab}} \pm 0.04$ \\
DM6 & $87.8^{\mathrm{b}} \pm 3.9$ & $4.28 \pm 0.04$ & $9.35 \pm 0.17$ & $5.07^{\mathrm{c}} \pm 0.15$ & $118.52^{\mathrm{c}} \pm 3.27$ & $10.17^{\mathrm{cd}} \pm 0.13$ & $2.01^{\mathrm{c}} \pm 0.05$ & $1.26^{\mathrm{bc}} \pm 0.03$ \\
RD & $94.4^{\mathrm{cde}} \pm 1.9$ & $4.44 \pm 0.08$ & $10.37 \pm 0.16$ & $5.93^{\mathrm{ef}} \pm 0.15$ & $133.82^{\dagger} \pm 4.34$ & $11.36^{\mathrm{g}} \pm 0.25$ & $1.94^{\mathrm{bc}} \pm 0.04$ & $1.33^{\mathrm{de}} \pm 0.03$ \\
\hline
\end{tabular}

AWG: Absolute weight gain; RWG: Relative weight gain; $\mathrm{Fl}_{\text {adj }}$ : Adjusted feed intake; FCR: Feed conversion ratio; PER: Protein efficiency ratio. Values reported are means of three replicates. Values reported are means of three replicates. Mean values in the same column with different superscript letter are significantly different $(P<0.05)$.

Table 7. Proximate composition of shrimp muscle at the start and at the end of the experiment (\% fresh weight).

\begin{tabular}{lcccc}
\hline & Water & Protein & Lipid & Ash \\
\hline Start of experiment & $79.5^{\mathrm{c}} \pm 0.2$ & $15.8^{\mathrm{a}} \pm 0.1$ & $1.4^{\mathrm{a}} \pm 0.1$ & $1.6^{\mathrm{a}} \pm 0.1$ \\
End of experiment & & & \\
CD & $77.7^{\mathrm{ab}} \pm 0.2$ & $17.6^{\mathrm{bc}} \pm 0.1$ & $1.6^{\mathrm{ab}} \pm 0.1$ & $2.0^{\mathrm{b}} \pm 0.1$ \\
DS2 & $77.1^{\mathrm{a}} \pm 0.1$ & $18.2^{\mathrm{d}} \pm 0.1$ & $1.6^{\mathrm{abc}} \pm 0.1$ & $1.9^{\mathrm{ab}} \pm 0.1$ \\
DS3 & $77.6^{\mathrm{ab}} \pm 0.4$ & $18.3^{\mathrm{d}} \pm 0.1$ & $1.5^{\mathrm{ab}} \pm 0.1$ & $1.9^{\mathrm{ab}} \pm 0.1$ \\
DS6 & $77.6^{\mathrm{ab}} \pm 0.4$ & $18.2^{\mathrm{d}} \pm 0.2$ & $1.6^{\mathrm{ab}} \pm 0.1$ & $1.8^{\mathrm{ab}} \pm 0.1$ \\
DI2 & $77.8^{\mathrm{ab}} \pm 0.2$ & $17.8^{\mathrm{c}} \pm 0.1$ & $1.6^{\mathrm{ab}} \pm 0.2$ & $1.8^{\mathrm{ab}} \pm 0.1$ \\
DI3 & $77.4^{\mathrm{ab}} \pm 0.2$ & $17.7^{\mathrm{bc}} \pm 0.2$ & $1.7^{\mathrm{abc}} \pm 0.3$ & $1.8^{\mathrm{ab}} \pm 0.1$ \\
DI6 & $77.8^{\mathrm{ab}} \pm 0.6$ & $17.5^{\mathrm{bc}} \pm 0.2$ & $1.6^{\mathrm{ab}} \pm 0.1$ & $1.9^{\mathrm{b}} \pm 0.1$ \\
DM2 & $77.9^{\mathrm{b}} \pm 0.1$ & $17.5^{\mathrm{bc}} \pm 0.1$ & $1.9^{\mathrm{bc}} \pm 0.1$ & $1.9^{\mathrm{ab}} \pm 0.1$ \\
DM3 & $77.5^{\mathrm{ab}} \pm 0.3$ & $17.4^{\mathrm{b}} \pm 0.1$ & $2.0^{\mathrm{c}} \pm 0.2$ & $1.9^{\mathrm{ab}} \pm 0.2$ \\
DM6 & $77.7^{\mathrm{ab}} \pm 0.1$ & $17.6^{\mathrm{bc}} \pm 0.1$ & $1.9^{\mathrm{bc}} \pm 0.1$ & $1.8^{\mathrm{ab}} \pm 0.1$ \\
RD & $77.3^{\mathrm{ab}} \pm 0.1$ & $17.8^{\mathrm{c}} \pm 0.1$ & $1.7^{\mathrm{abc}} \pm 0.1$ & $2.0^{\mathrm{b}} \pm 0.1$ \\
\hline
\end{tabular}

Values reported are means of three replicates. Mean values in the same column with different superscript letters are significantly different $(P<0.05)$ 
Figure 1. Molecular weight distribution of peptides in tuna head hydrolysates

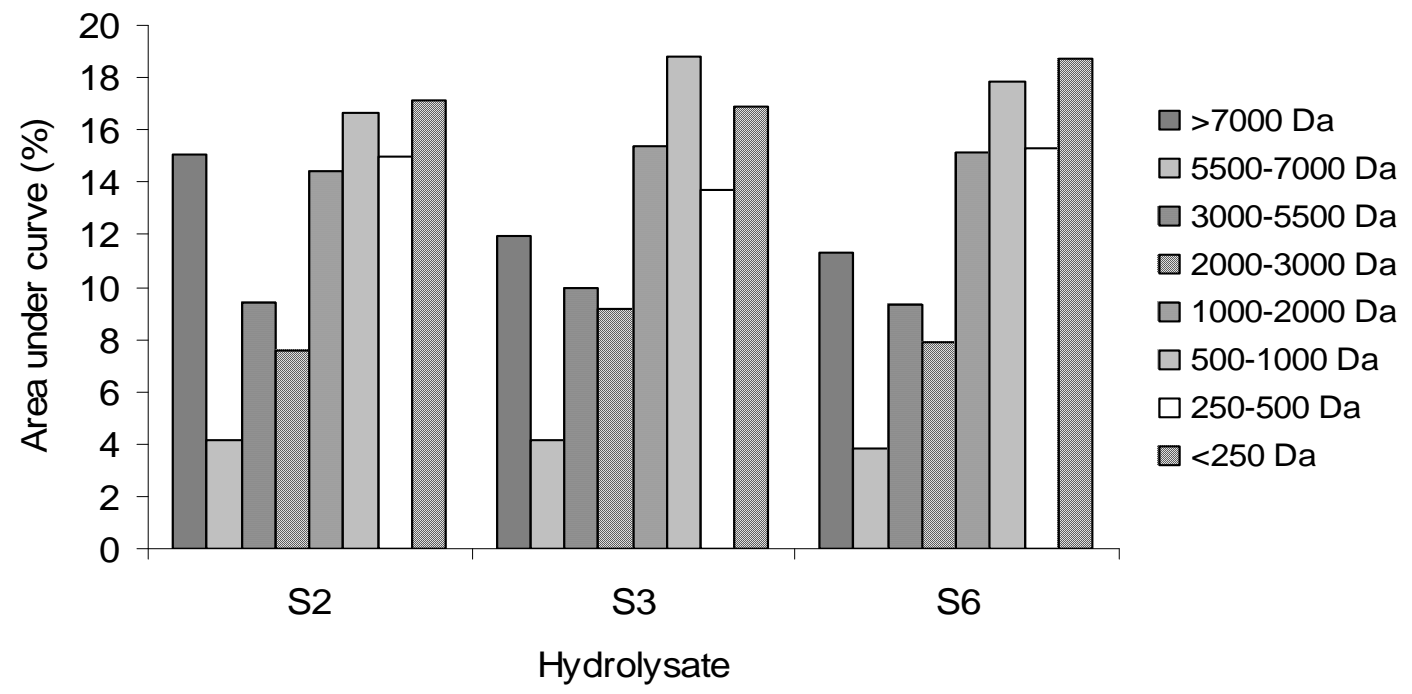

